\title{
The Viability of Alternative Call Center Production Models
}

\author{
April, 2002 \\ Forthcoming, Human Resource Management Journal \\ ROSEMARY BATT \\ and \\ LISA MOYNIHAN \\ Department of Human Resource Studies \\ New York State School of Industrial Labor Relations \\ Cornell University \\ Ithaca, NY 14853-3901 \\ Tel: (607) 254-4437 \\ Fax: (607) 255-1836 \\ E-mail: rb41@,cornell.edu
}

Paper prepared for the conference, "Call Centers and Beyond: The HRM Implications, Kings College, University of London, 6 November, 2001 


\section{The Viability of Alternative Call Center Production Models}

\section{Introduction}

Advances in information technologies and marketing techniques have led to a revolution in service delivery systems over the last decade. Whereas service delivery historically was decentralized and personal and service labor markets were local, advanced information systems and marketing techniques have made centralized remote servicing via technology-mediated call centers the preferred mode of customer-provider interaction for many firms. While data on call centers is difficult to procure, estimates are that call centers employ about 3 percent of the workforce in the US, 2 percent in the UK, and 1.3 percent in Europe (Datamonitor, 1998, 1999). US call centers were growing at an estimated annual rate of 15-20 percent annually in the 1990s (Purdue University, 1999).

To manage call center operations, firms have introduced industrial engineering models into customer services for the first time, mechanizing and routinizing work processes that historically were varied and complex. For firms, the economic benefits of shifting service delivery to call centers include enormous scale economies achieved through office consolidation, service automation, and process rationalization. For consumers, there are trade-offs: lower prices but also lower service quality as self-service menus shift labor costs to consumers and mechanized systems limit their choices. At the same time, the majority of call center workers experience a degradation in working conditions, with increased machine-pacing of work, routinization of work processes, boredom, and increased stress associated speed-up of job cycle times. Thus, the call center production model creates a classic conflict that pits workers against employers. With conflict built into the production system, the primary role of unions is to fight against oppressive working conditions and low wages, as exemplified in recent research on call center unionization (Taylor \& Bain, 2001).

Alternative strategies based on high quality professional service also exist, but they are costly and characterize a minority of transactions generally reserved for business and elite clients. The open question is whether some form of mass customization is viable for serving large numbers of consumers. The business strategy under mass customization is to compete on quality and customer loyalty as well as price. To do so, firms would logically invest in new technology to complement, rather than substitute, for labor. They would adopt a set of management practices that invest in the skills and abilities of the workforce, design work so that 
employees have opportunities to use those skills effectively, and create incentives that reward effort and commitment. In this paper, we refer to these practices as "high involvement practices". They may be viewed as a means to quasi-professionalize production level work. Compared to a mass production approach, this alternative should create better jobs for workers, better service for consumers, and better organizational performance. Under this alternative, unions are likely to spend less time in workplace grievances and more time on initiatives such as joint training programs. Yet, at a time when many manufacturing enterprises have moved away from a strict adherence to a mass production model to adopt high involvement work practices, many service firms have moved in the opposite direction. Production-line call centers proliferate.

The central question of this paper is whether a mass customization strategy coupled with high involvement work practices is an economically viable model for service and sales call centers. If so, under what conditions and why? To answer these questions, in the next section, we describe alternative models of call center management. In section III, we present a conceptual framework for understanding the relationship between management practices, workers reactions to those practices, and performance outcomes. We then review empirical evidence on these relationships, focusing primarily on studies of call centers or related service workplaces. In section IV, we draw on evidence from two recent quantitative studies of call centers to examine the performance outcomes of high involvement practices in this context. We close with a discussion and critique of existing evidence and suggestions for future research.

\section{Alternative Models of Service Delivery}

A useful way of distinguishing production models is along 4 dimensions: the use of technology, the skill requirements of jobs, the organization of work, and the use of other human resource incentives to reward effort. In this section, we outline three alternative models, which may be thought of as varying on a continuum in terms of investment in human capital and human resource incentives. At the low end is the classic mass production model, while at the high end is the professional service model. Between the two extremes is a range of hybrid models that we describe as mass customization.

\section{The Spread of Mass Production in Services}

Under classic mass production, the goal is to maximize volume and minimize costs. To achieve that goal, firms have used a combination of mechanization and Taylorism to rationalize the production. Technology is used to mechanize and automate production where possible. It is 
viewed as a substitute for labor; and labor is a residual cost to be minimized. Jobs are designed along the principles of Taylorism, with detailed functional specialization and time and motion studies to standardize work. Taylorist work organization minimizes skill requirements, discretion, and job cycle time. Learning is limited to repetition of simple rationalized tasks ("practice makes perfect"). Human resource practices to induce effort are built on fear of job loss and/or piece rate pay systems (or in call centers, individual commission pay). The approach assumes that jobs can be designed to be turnover-proof, with workers as replaceable parts.

The application of mass production principles in service activities has been uneven for at least two reasons: the intangible nature of services limits the use of machine pacing and one party to the production process - the consumer - is not under the control of management. In clerical work, for example, machine pacing was not possible, but the application of Taylorist principles was effective in creating clerical typing pools with efficient, standardized output. In customer-contact work, however, variation in consumer preferences introduces uncertainty into the production process. As a result, service managers also use work rules and norms to standardize work behaviors - what Leidner (1993) refers to as "routinization." To rationalize service production, therefore, firms have typically relied less on mechanization and more on Taylorist principles and routinization of behaviors.

Call centers, however, represent an exceptional case in which mechanization has spread into customer-contact work. For purposes of understanding today's call centers, an instructive case is the evolution of operator services in the large telephone bureaucracies such as AT\&T and British Telecom. A hundred years ago, operator service jobs were considered high skilled jobs in the "high tech" telephone industry. They were complex and varied, requiring physical manipulation of cords, social interaction skills, and diagnostic assessments of faulty telephone circuits. From 1900 on, AT\&T adopted Taylorist principles to standardize work methods. It also developed personnel policies to control work behavior, including the recruitment of white middle class women with a diploma or high school degree -- because they matched the characteristics of the middle and upper-class people who could afford telephones. Selection procedures required women to pass extensive entrance examinations; training covered rules of behavior, speaking, and scripts; and intensive monitoring and discipline was reflected in the ratio of supervisors to workers, which was typically 1:6 (Schacht, 1985).

From the 1920 s on, however, the company began to mechanize operations, fragmenting 
of once varied jobs. Mechanical switching made it possible for customers to dial their own local calls by the 1920s, and long distance calls by the 1950s. In the 1970s, digital systems further eliminated operator work by letting customers use credit cards to direct dial long distance calls. Each new technological advance eliminated large numbers of operator jobs, while reducing the variety and complexity of the remaining jobs: eliminating the physical side of the job, reducing the types of calls, and eliminating the diagnostic work (Kohl, 1993:104). In the 1980s and 1990s, job fragmentation and displacement continued through the use of automated response and voice recognition systems (Kohl, 1993:105). In 2000, the typical telephone operator handles 1000 calls per day, a job cycle time of about 21 seconds per call, significantly lower than the average 60 second job cycle time of auto assembly workers.

AT\&T's mechanization strategy produced dramatic improvements in productivity, with operators constituting 60 percent of the telephone workforce in 1920, 44 percent in 1950, 14 percent in 1980, and 4 percent in 1996. Automation spread to back office jobs (clerical, data processing) over the course of the last century, but most customer contact operations resisted rationalization because of the variety and uncertainty introduced by the consumer. Research in operations management in the 1960s and 1970s attempted to solve that problem by limiting customer variation through standardized options (Levitt, 1972; Chase, 1978) - for example, in fast food or retail sales operations (Leidner, 1993).

Telephone operator call centers provide a model of efficiency that managers in today's diverse call centers seek to emulate. The goal is to apply industrial engineering techniques to more complex service and sales interactions in order to increase volumes and reduce call handling time. The dramatic spread of call centers over the last decade or so has occurred because of advances in front-office automation. Automatic call distribution and routing systems, voice recognition systems, and other innovations made it possible to consolidate local service and sales centers into remote, centralized distribution channels serving much wider geographic areas. Large centers achieve scale economies through greater labor flexibility and by spreading call loads over larger numbers of workers.

\section{The Professional Service Model}

At the opposite end of the spectrum from mass produced services is the professional service model, with the goal of providing quality service. To do so, technology is used as a complement to labor, the formal education and specialized skills of employees are very high, the 
design of work builds on the independent discretion of professional employees who collaborate as needed with other specialists to provide service and who are rewarded with high relative pay, benefits, and employment security. The professional model -- exemplified by lawyers, health care professionals, and others -- is based on the idea of building long term personal relationships of trust between professionals and their clients, what management theorists refer to as relationship management (Gutek, 1995). Clients are willing to pay a price premium for quality, customized services. Variations of this model now cover a much wider range of service occupations in, for example, high tech specialties and business services. Recent interpretations of this model reject the idea of the individual professional working alone in favor of the idea that professional service depends on, and is embedded in, communities of practice - informal relationships between professionals that serve as a basis for learning, problem solving, and sharing of contextually specific tacit knowledge (Brown \& Duguid, 1991; Orr, 1996).

In the context of customer service and sales operations, the professional model would include the use of college-educated account executives, who are dedicated representatives serving particular business clients. They provide high quality services through a combination of high general skills (formal education) coupled with firm specific skills (their deep tacit knowledge of the firm's products, work processes, and customer characteristics). They provide a complete range of services and generally draw on other teams of experts in their company to meet customers' demands. Thus, firm specific social capital is also valuable, which is defined by the personal relationships of trust among professionals in the firm and between professionals and their clients. The competitive performance advantage for firms that adopt the professional model is that their services are valuable, rare, and hard to imitate (Barney, 1995). The longer a client stays with one provider, the more difficult it is to shift to another provider not only because of personal relations of trust, but because of the wide variety and complexity of services that are provided and the negotiating power and flexibility that come from long term relations.

\section{Mass Customization Models}

Between the mass production and professional service models are various hybrid models that may be generally classified as mass customization. The goal is to compete on quality and customization as well as price. To do so, firms would adopt some level of automation and process reengineering found in mass production models coupled with some level of attention to service quality and customer loyalty found in the professional model. This approach may be a 
more economically viable than a classic mass production model because consumers in today's mass markets demand quality, customization, and innovation as well as reasonable prices (Pine, 1993). For this reason, many manufacturing firms have shifted from classic mass production to adopt some level of high involvement work practices, and a reasonable number of empirical studies show that these practices lead to better performance in that setting (Ichniowski et al., 1996; Becker and Gerhart, 1996; Appelbaum et al., 2000). It is reasonable, then, to examine whether they produce better performance in call centers, which typically have been designed along a classic mass production model. If companies compete on the basis of quality, customization, and price, then call center workers need the skills, discretion, and incentives to handle relatively complex interactions with customers. A recent qualitative case study describes what a high involvement strategy in a call center might look like (Hutchinson, Purcell, \& Kinnie, 2000).

In this paper, we define high involvement practices to include: a) technology used as a complement rather than substitute for labor; b) high relative skill requirements of jobs, c) work designed to provide opportunities for discretion and worker collaboration, and d) incentives such as high relative pay and employment security to reward effort. Our definition is consistent with much of the prior literature on high involvement or high performance work systems (MacDuffie, 1995; Huselid, 1995; Delery \& Doty 1996; Appelbaum et al., 2000). While there are several criticisms of this literature (see Wood, 1999; Wright et al., 1999), we use this framework in order to relate the discussion of call center models to the literature on manufacturing, where the high involvement model has been widely discussed.

However, we view the concept of high involvement along a continuum, from low levels in the classic mass production model to high levels in the professional model. In other words, these management practices provide a vehicle to quasi-professionalize the employment of production-level service workers. We also view it as a relative concept: high relative to what? For example, in an industry where the norm is a classic mass production model, then firms may realize improvements with only modest additional investments in training, technology, and work redesign. In business services, by contrast, a professional or high involvement model may be the price of entry, and variation in management practices may produce only small relative gains. 


\section{Alternative Performance Models: Theory and Evidence}

The high involvement and high performance literatures are theoretically undeveloped, and researchers have questioned what is in "the black box" linking management practices to performance outcomes. However, implicit in these paradigms are micro-level theories of organizational behavior (e.g., Lawler 1986). One line of argument is that management practices influence employee attitudes and motivation, which in turns affects their performance. A second line of argument is cognitive: management practices influence employee skills and their ability to learn and solve problems on the job. In this section, we draw on research from organizational behavior and human resource studies to discuss the empirical evidence for these arguments, focusing primarily on studies of service workplaces.

\section{Management Practices, Affective Reactions, and Performance}

The idea that management can influence the performance of workers via an effect on their attitudes has a long history in organizational behavior. The large literature on work design showed that enhanced job characteristics (e.g., autonomy, variety, ability to complete a whole task, Hackman \& Oldham, 1980) are significant predictors of worker satisfaction (Cotton, 1993). Reviews of the literature on self-managed teams provide similar conclusions (Cotton, 1993; Cohen \& Bailey, 1997). However, these studies failed to find that happier workers are more productive (Locke \& Schweiger, 1979). More recent studies have examined a fuller range of high involvement practices and also report little evidence that better performance works through better employee affective outcomes. For example, Godard (2001) analyzed survey data from 500 Canadian workers and found that high involvement practices were associated with greater intrinsic rewards (such as satisfaction and commitment), but also greater reported stress (Godard 2001). Ramsay, Scholarios, and Harley (2000) analyzed the 1998 UK Workplace Employee Relations Survey and found significant positive relationships between high involvement work practices and several performance outcomes as reported by managers. However, they found only mixed support for the idea that employee perceptions mediate the relationship between management practices and performance. Neither of these studies differentiated between manufacturing and service organizations, however.

Nonetheless, several researchers in service management have pursued this line of thinking based on the idea that worker attitudes are likely to be more important in customercontact jobs because workers' dissatisfaction can more readily spill over into customer 
interactions, leading to poor service. The most elaborate theory (the service profit chain) links human resource practices to employee satisfaction and loyalty, which in turn inspires customer satisfaction and loyalty, ultimately resulting in higher profits (Heskett et al., 1997). The HR practices discussed in this literature are similar to those found in the high involvement literature. A more recent incarnation of this idea develops a set of performance metrics ("the balanced scorecard") that capture all of the links in the service profit chain (Kaplan \& Norton, 1996).

Some empirical support for these arguments comes from Schlesinger and Zornitsky (1991), Tornow and Wiley (1991), and Wiley (1991), who found a positive correlation between employee job satisfaction and customer service ratings. Ulrich et. al. (1991) found that at Sears, negative customer service ratings were correlated with higher levels of employee turnover and higher use of part-time staff; at Ryder Truck, negative customer ratings were significantly correlated with high employee turnover and high Workers' Compensation claims. Loveman (1998) is the first to test correlations along a series of links (internal service quality -> employee satisfaction $->$ employee loyalty $->$ external service quality $->$ customer satisfaction $->$ customer loyalty). Based on employee and customer data from 479 branches of a multi-site regional bank, he found significant correlations between many of the variables measuring relationships along the chain.

A similar line of argument is found in the "service climate" literature, developed by Schneider and his colleagues. They, have used worker surveys to capture whether management creates a positive "service climate" - an overall environment or organizational culture that supports quality service. This approach differs from the high involvement literature in that the latter attempts to measure specific management practices, such as training or the use of teams, rather than perceptions of the environment. Several researchers have used Schneider's framework and have found significant positive relationships between worker perceptions of service climate, worker attitudes, and customer satisfaction (Schneider et. al., 1985, 1992, 1998; Schmit and Allscheid, 1995; Johnson, 1996). Sargent and Frenkel (2000) also found that support from supervisors, teams, technology, and other departments led to higher worker satisfaction, commitment, and self-reported service quality. However, the causal relationships are not entirely clear in this line of research, as some researchers have found that customer satisfaction leads to worker satisfaction (Ryan, Schmit, and Johnson, 1996). 
Another emerging line of research, set primarily in call centers, focuses on various measures of individual well-being, including stress, anxiety, depression, emotional exhaustion, and burnout in call centers (Holman 2001; Holman, Chissick, and Totterdell 2001; Deery, Iverson, and Walsh 1999; Singh, Goolsby and Rhoads 1994; Singh, Berbeke, and Rhoads 1996; Singh 2000). Holman and colleagues found significant relationships between human resource practices such as job design and electronic monitoring and worker well-being and satisfaction.

Deery et al. (1999) found that characteristics of call center work, including customer interactions, scripts, routinization, workloads, and managerial emphasis on quantity, were associated with emotional exhaustion, which in turn predicted absenteeism. Singh and colleagues have focused on the relationship between stress and burnout on the one hand, and performance on the other. Singh (2000), for example, found that worker burnout with customers is associated with lower self-reported service quality. He also found that task control, a construct similar to autonomy or discretion over work, was the most important source for reducing burnout. A particularly promising series of studies conducted at the University of Michigan has shown that electronic monitoring is significantly associated with worker disaffection and stress (Carayon, 1993).

There are several limitations to these studies. First, most do not incorporate measures of technology into their analyses of other management practices. Second, most examine a limited number of management practices, focusing instead on particular facets of work, such as work design or electronic monitoring. Third, they typically focus on individual workers rather than workers in the context of work groups and their social relationships. Fourth, they do not link worker outcomes to objective performance measures. Fifth, they do not deal with the critique of reverse causality. Sixth, they do not explore the conditionality of their findings. For simple transactions, for example, customers may prefer efficient, anonymous and impersonal exchanges, as Sutton and Rafaeli (1988) found. In their study of convenience stores, customers wanted speed; employee use of more positive affect or personal interaction was negatively related to store profitability. In sum, while there is promising research linking management practices to workers' attitudes and emotional state, there is much work to be done in explaining the relationship between affective or emotional outcomes and work performance.

\section{The Cognitive Argument}

Research on the cognitive argument linking management practices to performance has received less attention than the affective one. The cognitive argument has individual and group- 
level dimensions. The individual-level argument is similar to the logic of total quality management (TQM): individual workers closest to the point of production have the tacit knowledge to solve problems, so that providing workers with greater discretion should allow them to solve problems and continuously improve production. While there is some evidence that TQM methods are associated with better quality, there is little research regarding the actual mechanisms through which this occurs - for example, how individual learning or knowledge sharing occurs in these settings.

A second line of reasoning is that organizing work into self-managed or semiautonomous work groups leads to better performance because workers with interdependent tasks can solve problems collectively. This is a basic premise in the sociotechnical systems and group effectiveness research. While research in manufacturing settings has shown considerable support for this idea (Cohen and Bailey, 1997), empirical studies in service settings have provided mixed results. For example, Gladstein (1984) found a significant positive relationship between team processes and self-reported effectiveness, but not with objective sales, in a study of 100 sales teams in telecommunications. Yammarino and Dubinsky (1990) found that group autonomy was positively related to managerial ratings of sales workers in retail sales, but not insurance. A study of 100 matched pairs of self-managed and traditionally supervised work groups in telecommunications (Cohen and Ledford 1994; Cohen, Ledford, and Spreitzer 1996) reported that team and manager evaluations (but not supervisor evaluations) of craft and administrative support teams were higher; but those for customer service and sales workers were not. Campion and his colleagues tested Hackman and Oldham's (1980) model of job characteristics, measured at the work group level; they found it predicted significantly better objective performance among teams of clerical workers (Campion et al., 1993) and knowledge workers (Campion et al., 1996) in a large financial services firm.

These studies, however, do not explore why teams are associated with better performance. In manufacturing settings, the benefits to teams are more obvious because workers on a production line have interdependent tasks; job rotation and cross training provide labor flexibility (filling in for absences, etc.). In customer contact settings such as call centers, by contrast, workers interact with customers to complete a transaction, not with other workers. The customer is assumed to get better service if one employee completes the transaction, as opposed to multiple hand-offs or consultation among employees. Computer technology also reinforces 
the independence of workers, each of whom has his or her own computer. In these settings, a cognitive explanation for better performance in teams is more plausible. For example, Batt (1999) studied self-directed teams in call centers and found that, compared to traditionally supervised groups, the teams had significantly higher self-reported quality and 9 percent higher objective sales revenues. More importantly, the interactive effect of self-directed teams and new information technology increased sales by an additional 18 percent. This result indicates that teams learned to use the new technology faster than traditionally organized groups, suggesting a cognitive explanation.

Interest in cognitive explanations of group effectiveness has grown recently, with researchers beginning to focus on information processing and knowledge sharing in groups as sources of performance gains (Hinsz, Tindale, and Vollrath, 1997). Theories of group knowledge transfer and group memory consider the extent to which individual group members know the domains of expertise of other members and are able to access and/or utilize that information for the benefit of the group. Some researchers have conceptualized shared knowledge as a collective good, with each team member working from the same set of premises or team mental model (e.g. Cannon-Bowers, Salas, and Converse, 1993). Others have viewed shared knowledge as a complementary process, with each member contributing his or her unique expertise to the group (e.g., Stasser, 1992). Three main theoretical approaches to group knowledge are team mental models theory (Cannon-Bowers, Salas, and Converse, 1993; Klimoski and Mohammed, 1994; Mathieau et al, 2000), group information sharing theory (Stasser and Titus, 1985), and transactive memory (Wegner, 1987; Liang, Moreland, and Argote, 1995). To date, however, this literature is at an early developmental stage. Most of it is conceptual or based on lab studies, and measures of central constructs such as group knowledge, knowledge sharing, information exchange, and learning are yet to be developed.

\section{Recent Studies of Call Center Performance}

In this section, we draw on data from two recent studies of call centers to flesh out the meaning of high involvement work systems in this context. In the first study we explore the affective explanation for the relationship between management practices and performance, by examining the relationship between high involvement practices, quit rates, and sales growth in a sample of 354 call centers. In the second study, we probe the cognitive explanation by moving to the work group level of analysis. We use a survey of 419 workers in 4 call centers and match 
their responses to objective measures of call quality. We focus particularly on the relationship between team-based work, knowledge sharing among workers, and performance outcomes.

\section{High involvement Practices, Quit Rates, and Sales Growth}

This study was based on a multi-year qualitative and quantitative research project on call centers in the US telecommunications industry. The quantitative data is based on a nationally representative survey of managers of 354 call centers. Prior analyses of this data revealed that production models varied significantly by the customer segment served (Batt, 2000). At the low end, telephone operator centers conformed to the classic mass production model discussed above. Centers serving residential customers also followed a mass production model, but with the rigidities of the production system somewhat relaxed. Centers serving large businesses, by contrast, were more likely to adopt a professional service model, while those serving small businesses adopted an intermediate model between mass production and professional service. In this paper, we analyze the data in a new way, by considering the range of variation in management practices within each segment and its relationship to performance outcomes.

\section{Methods}

The call centers in this study provide service and sales of telecommunications services to residential and business customers. The sample is a stratified random sample drawn from the Dun and Bradstreet listing of establishments. Establishments were stratified by size (10-99 employees, 100-plus employees), by industry segment (cellular, wireline, cable, and Internet), and by state location. A 52-minute telephone survey, administered to the general manager at each call center, covered questions related to basic industry characteristics, management strategies, and work and human resource practices. The response rate was 53 percent. See Batt (2002) for a fuller description of methods and measures.

To measure high involvement work practices, we used ten survey questions that captured skill levels, work design, and HR incentives. The skill requirements of jobs were measured by two variables: a) years of formal education of the typical (median) core employee; and b) the months of formal and on-the-job training needed for a new employee to become proficient. For work design, we used two measures for individual discretion and two for employee collaboration in teams. The individual discretion scales use a 1-5 Likert response format, where 1 is little or no control and 5 is complete control. Discretion over work methods included eight questions adapted from MacDuffie (1995) (degree of influence over tasks, tools, work methods, pace of 
work, schedules, vacations, and technology design, Cronbach's alpha $=.79$ ). Discretion over customer interactions was measured by 2 questions developed for this study: control over handling non-routine requests and control over the pace of serving customers (Cronbach's alpha $=.60$ ). Team participation includes the percent of employees that participate in regular off-line problem-solving groups and the percent that participate in self-directed teams.

Human resource incentives are of four types: on-going training, employment security, pay level, and electronic performance monitoring. On-going training indicates a firm's commitment to employee development and is measured by the number of weeks of training a typical core employee receives each year. Pay is the natural log of the median annual base pay of the core workforce. Employment security is the percent of the core workforce that is permanent and fulltime, as opposed to part-time or contingent. Employers use part-time and contingent workers to cut costs (Houseman, 2001), and under these circumstances, fulltime workers worry that their jobs will be turned into part-time or contingent ones, with lower pay and benefits. Electronic monitoring is measured by the percent of work time that is typically electronically monitored (reverse coded). To create an additive index of high involvement practices, we transformed all ten variables to z scores (mean zero, standard deviation 1) and took their mean value. To make the index more transparent, we translated it into a 0-100 scale.

Performance outcomes included the average annual quit rate and the percent change in sales in the prior two-year period. The measure of quits excludes discharges, retirements, transfers, and promotions. The measure of sales growth is the natural log of the percent change in the value of sales to the particular customer base served by the center.

\section{Results}

For an initial analysis of the data, we divided call centers into those that fell below the mean of the high involvement index for each customer segment and those that fell above the mean (see Table 1). On average the telephone operator centers scored 27.5 (the sample was too small to meaningfully divide it). For residential centers, the bottom half of the distribution scored an average of 32.6 points, while the top half scored 53.1 points. For small business centers, the scores were 36.5 points and 58.5 points respectively; and for large businesses, 48.8 and 72.3 points. In sum, taking a simple split-half comparison, we found large and significant differences in management practices within each market segment. 
These differences in management practices translated into large and significant differences in quit rates and sales growth. Within the residential mass market, centers that adopted a lower involvement strategy had over twice the employee quit rates as their counterparts that adopted a higher involvement strategy (21 percent versus 9 percent). A similar pattern exists for the small and large business centers, although the size effects are not as large. Similarly, with respect to sales growth, those centers adopting a higher involvement approach to serving residential customers had more than twice the rate of sales growth compared to their counterparts adopting a lower involvement model (36.8 percent versus 16 percent). Again the effects are similar but not as large for the small and large business segments.

In further analyses, we analyzed the data using multivariate models, with controls for product market characteristics, organizational characteristics, and customer segment. We found that the high involvement index significantly predicted quit rates and sales growth, and that the quit rates partially explained the relationship between management practices and sales growth (see Batt, 2002). That is, quit rates are not only detrimental because of the added costs of employee recruitment and training, but new workers have a learning curve that makes them initially less productive - a period of time that managers estimate is about 6 months in residential service centers. We also found that the performance benefits were greater in magnitude for centers serving the residential market and to a lesser extent, those serving small business. We interpret this to mean that high involvement practices are rare in more cost-conscious markets, but they confer value because employees are better able to meet the demand for customization and service bundling.

To translate the high involvement index into more practical terms, we compared the centers in each segment above and below the mean of the high involvement index along a range of specific management practices (Table 1). For example, the years of education of the typical call center employee is an instructive indicator. For operators, it is 12 years (a high school diploma). For lower involvement residential centers, it is 12.5 years, while for higher involvement centers, it is 13.5 years. The formal educational qualifications of employees continue to rise in the small and large business centers, with lower involvement centers in large business hiring workers with 2 years of college, and higher involvement centers hiring those with a 4-year college degree. Most of the indicators of management practices follow a similar pattern, with significant variation not only across different customer segments, but within them 
as well. However, some show only modest variation, as in on-going training, which is low across the board.

For purposes of considering the viability of mass customization strategies in call centers, we want to focus this discussion on the residential call center data. It is here that there is the greatest tendency is to adopt a mass production model. These data suggest that a high involvement approach would include hiring employees who have at least a year or so of formal education over a diploma (secondary or high school) degree. The job is defined as relatively complex, requiring initial training of 5 weeks on average coupled with on-the-job learning of about 5 months before employees are fully proficient. While electronic monitoring is used, it is not pervasive during the entire day (in this case, less than 40 percent of work time is electronically monitored). This is due in part to the fact that workers do not spend 100 percent of their day on-line (in this case they spend 70 percent of their time on line). Consistent with this picture, workers handle fewer customers per day -- 72 as opposed to 128 in the lower involvement centers - although the average call is only modestly longer (6.4 versus 5.4 minutes). Workers appear to be working smarter rather than longer, with work diversified through offline tasks, including participation in problem-solving teams (on average, over 60 percent of the workforce regularly participate in offline teams in the higher involvement centers). Also, on average almost 30 percent of the workforce is organized into self-directed work groups. Moreover, the higher involvement centers provide considerably greater opportunities for internal promotion and employment security. There also are remarkable differences in the use of layoffs, with the lower involvement centers resorting to on-going layoffs and hiring 20 percent of the workforce into part-time or temporary positions. The higher involvement centers, by contrast, made almost no use of layoffs and used part-time and contingent employment for less than 10 percent of the workforce. Finally, base pay in the higher involvement centers is 24 percent higher, and total pay is 37 percent higher than in the lower involvement centers (notably, however, these differences are not as high as the differences in sales growth of 130 percent between the lower and higher involvement centers).

It is also worth noting what this model is not. It is not a fully professional model. The higher involvement residential call centers are still call centers that provide technology-mediated service, rely on electronic monitoring, and allow modest opportunities for employees to use their independent discretion to serve customers. They use a limited number of contingent workers to 
provide labor market flexibility and have 16 percent of pay that is variable or performancebased. They resemble the approach to management typically found in centers serving small and medium-sized business customers.

In sum, this nationally representative data on US call centers in telecommunications indicates that high involvement work practices are associated with significantly lower quit rates and higher sales growth. Our analysis also provides a concrete idea of what types of management practices have been adopted to accomplish these results. It suggests that call centers serving the mass market may well do better economically if they adopt the kinds of management practices currently found in centers serving small business. It also suggests that small business centers should resist the temptation of shifting to a more production line approach to service.

\section{Team-based Work Systems, Knowledge-sharing, and Performance}

In our second study, we sought to understand more fully how the organization of work and incentives influence workers' ability to serve customers. As indicated in our review of the literature, most researchers assume that group-based work organization is only appropriate when work tasks are highly interdependent, a condition not met in customer service centers. However, the benefits of knowledge sharing and learning found in prior research on teams in call centers (Batt, 1999) led us to examine this question empirically.

\section{Methods}

This study involved qualitative field work and survey and archival data collection in 4 call centers in one company. Workers in these call centers serve employees in companies by answering service and billing questions regarding payroll, medical, pension, and life insurance benefits. The company in this case administered the HR benefit plans for 100 companies. Workers were organized in teams, with each team dedicated to one (sometimes 2 or 3 ) companies. We randomly sampled 50 percent of the workers in each work group having more than 2 members and less than 25. Our final sample includes 333 workers in 78 teams. The response rate for the mail survey was 53 percent. The respondent pool is 72 percent female and 41 percent married. The age of the participants ranged from 20 to 63 years, with a mean age of 30.2 years. We matched workers' survey responses to objective archival data on call quality.

In general, this non-union company adopted an approach to call center management that, compared to a mass production model, falls within the concept of a high involvement model -with some features resembling those in the small and large business centers described in the 
telecommunications study. The formal education of workers is quite high (almost $60 \%$ of the sample has a 4-year college degree). Workers use an average of 7 software programs, and typically spend $65 \%$ of their day on the phone handling incoming calls and $35 \%$ doing offline follow-up. Work is organized into teams serving particular clients, and almost all employees are fulltime permanent staff. However, average interaction time with customers is only 4.5 minutes and average annual salary in 2000 was relatively low, at $\$ 26,335$.

Our survey questions captured three dimensions of the work system: the use of technology and skill level of jobs, work design, and supportive HR practices. We measured the skill level of jobs by the number of software programs used and the frequency of program updates. Work design was measured by the extent of task interdependence, resource interdependence (shared information in computer data bases), and task variety. HR incentives included the extent to which work groups had shared goals and outcomes, shared training, and group-based recognition and rewards. Knowledge sharing was conceptualized along two dimensions: how much workers knew about each other's expertise and how much they actually used other workers' knowledge to solve work-related problems. Performance outcomes included the group's average call handling time, average call quality as determined by a company audit, perceived process loss (whether workers perceived knowledge sharing as resulting in productivity losses), the extent to which workers relied on peer learning, and the innovative problem-solving reported by group members (for a full description of methods and measures, see Moynihan and Batt, 2001).

\section{Results}

For our analysis, we examined variation in the implementation of work practices at the group level to assess what predicts better performance outcomes. Table 2 provides the results of bi-variate correlations between work practices and knowledge-sharing on the one hand, and knowledge-sharing and performance outcomes on the other. In general, we found that all three dimensions of the work system were significantly related to knowledge sharing, with groupbased work design and shared outcomes and recognition providing the strongest correlations to knowledge sharing. Knowledge sharing, in turn, was significantly positively related to objective call quality and perceptions of innovative problem solving and peer learning. It was negatively related to process loss and not significantly related to call handle time, suggesting that the time that workers take to share their knowledge does not significantly interfere with their productivity. 
In analyses using structural equation modeling, we found that these relationships held, with a single index of knowledge sharing mediating the relationship between skill level, work design, and group-based incentives on the one hand, and the outcome variables on the other. Job satisfaction was also an outcome of knowledge sharing. It did not explain the relationship between work practices and most outcomes, but did predict lower call handling time (Moynihan and Batt, 2001).

These findings suggest that team-based work systems in call centers have a somewhat different meaning than in manufacturing settings, where much of their value lies in job rotation, broadened job responsibilities, multi-tasking, and labor flexibility. In call centers, being in a team does not alter the nature of the work itself, which consists of interacting individually with customers to respond to their inquiries. Almost all jobs are identical so, with the exception of team leader positions, there are few jobs to rotate. Moreover, collaborative structures are not "technically required" by the technology, as in jointly producing a good along a machine-paced process. Rather, in call centers, collaborative structures must be self-consciously created by workers and supervisors. Those who are more successful in creating these collaborative structures are able to provide better service.

Thus, we found that the primary value of team-based work design is to provide an opportunity structure for employees to improve their skills and abilities. The primary value of group-based incentives (such as group-based goals, performance appraisal, recognition, and rewards) is to motivate workers to continually learn from each other by sharing information, specific areas of expertise, and innovative solutions to problems. The idea of emphasizing teambased work in call centers may appear counter-intuitive because the primary work task is individual employees interaction with customers. However, in order to serve customers well, employees need to be continually absorbing new information about customer services or new technologies and learning how to solve new customer inquiries. The information and knowledge needed to do the job effectively is constantly shifting. In this type of environment, workers with different areas of expertise are in the best position to assist each other. Supervisors are likely to be too removed from daily customer interactions to maintain high levels of expertise in the wide range of topic areas that are required. 


\section{Discussion and Directions for Future Research}

In this paper we outlined three alternative production models and discussed their applicability to call center management. We contrasted the classic mass production model with the professional service model and presented a hybrid mass customization model that incorporates the efficiency gains of mechanization and the attention to quality service found in the professional model. We then presented a conceptual framework that identifies potential links between management practices, workers' affective and cognitive reactions, and performance outcomes. We used this framework to review literature on service workplaces in organizational behavior and human resource studies and to identify what empirical evidence we have regarding the causal links between management practices and performance outcomes. We then summarized two recent studies of call centers, one that examines the relationship between management practices, affective reactions (quit rates), and sales growth and one that assesses the relationship between management practices, cognitive reactions (knowledge sharing), and performance. These studies provide two examples of recent quantitative research on call center performance.

There are several limitations of existing research on call center performance and studies of service workplaces more generally. Some of these criticisms also apply to the high involvement literature more generally. A first critique concerns the performance measures that have been used. Most studies capture one or two context specific outcome measures - such as productivity or quality -- that do not adequately capture the economics of the production system. In our study of call centers in telecommunications described above, for example, we were not able to calculate the net effect of high involvement practices on labor costs. Thus, while high involvement practices were associated with lower quit rates and higher revenues, we were unable to assess the effect on net revenues, or profits, although we were able to examine wages. This is an important issue, because, in contrast to manufacturing where labor costs are now typically less than 25 percent of total costs, in service operations they typically comprise the majority of costs. As Cappelli and Neumarck (2001) point out, high involvement work practices are costly due to high investments in training and high relative pay. Therefore, whether there is a net performance gain from high involvement practices is an empirical question that is likely to vary with the relative labor intensity of an activity. The labor-intensive nature of services coupled with tight profit margins may limit the utility of high involvement practices in mass markets. 
A related issue is that our empirical studies do not examine the trade-offs among different types of outcomes. In our study, we were able to measure sales growth, but not customer service ratings. Of particular importance in call centers is whether quality service and sales may be jointly maximized. In manufacturing contexts, researchers have demonstrated that improving quality and efficiency can be mutually reinforcing by eliminating defects and waste (MacDuffie, 1995; Appelbaum et al., 2000). In customer services, however, the relationship between speed and efficiency and service quality are more ambiguous. In simple transactions, customers appear to want quick responses; but for many inquiries, quality of service is related to how long the service rep is willing to take to explain product features and answer inquiries. In the first case, quality and efficiency are complementary, while in the second, they appear not to be.

This observation leads to a second critique. In order to examine the relationship between quality and efficiency, we need to better understand the use of technology and operations management in call centers. Operations management research has focused on developing algorithms for efficient staffing patterns based on past patterns of call load volumes. The entire calculus focuses on increasing volume and minimizing labor costs. Human resource and industrial relations scholars, by contrast, have focused on understanding the organization of work and human resource practices with little attention to understanding the logic of operations management, or the technology that undergirds call center operations. We have not, for example, developed effective measures of how technology use varies, especially in call centers and other service workplaces, and what implications that has for production outcomes. If we are to engage in debates over the relative merits of alternative production models, we must do a better job of understanding the assumptions and research findings in operations management.

Third, analysis of the causal relationships linking management practices to performance needs to move forward. The research on worker satisfaction has traditionally failed to show a link to performance, but studies linking workers perceptions to actual customer satisfaction surveys is promising. As indicated above, however, this research should consider a much fuller range of performance outcomes. The research on emotional exhaustion and stress is particularly promising, but few studies have made the link to performance outcomes. The research on cognitive models is in its infancy, but an important line of inquiry for the future. Given the firm specific, tacit nature of knowledge and the on-going change in information in customer service 
operations, knowledge sharing and collaboration are likely to be important sources of performance gains that have been overlooked in the past.

In addition, we need to a more complete assessment of the implications of individual versus collaborative forms of work organization. Collaborative forms of work organization have the potential both to improve learning and problem solving and to reduce emotional exhaustion and stress. Yet, these effects on workers and their relationship to performance have not been tested in the current literature. Moreover, whether work is organized on an individual basis (typically coupled with commission pay) or a group model (perhaps accompanied by some form of group gainsharing) has other ramifications for workers and their unions. The individual sales model not only pits workers against each other and undermines cooperation and income security for many workers, it erodes the social fabric of the workplace and makes it harder to build solidarity and unionize or represent workers. For example, since the introduction of individual commission plans at US West in the mid-1990s, turnover has risen to 60 percent annually and the Communication Workers of America (CWA) that represents workers has found it much more difficult to attract workers to assume union steward positions.

Fourth, we need to integrate a better understanding of marketing and consumer behavior into our research on call centers. There are many market transactions in which customers want simplicity and speed, comparable to directory assistance operators or mass telemarketing. For these transactions, mass production models are likely to be sufficient, and firms will continue to pursue automated solutions, as exemplified in the evolution of telephone operator jobs. The question is whether the production line approach will continue to dominate a wider range of more complex service interactions, and how consumers will respond. Currently, consumer satisfaction with call center service is notoriously low, at 54 percent according to a recent US survey (Purdue University 1999). Consumers are particularly dissatisfied with the process of service delivery -- the length of time and alienation associated with automated voice recognition systems, the frustration with finding their way through a maze of venues that often fail to connect the customer with the appropriate provider, the fragmented delivery of services requiring separate contacts for different types of service offerings, the confusion and complexity associated with on-going changes in product and service features.

However, there appears to be little open consumer action against companies. On the one hand, marketing researchers assume that customers can be trained to accept new service routines. 
They define customer satisfaction as the gap between expectations and actual service, so that if customer expectations can be manipulated, customer dissatisfaction can decline even if the actual service remains unchanged. Thus, arguably the recent rise in customer dissatisfaction is a temporary phenomenon that will disappear over time as consumers adjust to new standards of self-service. Historic examples of customer adaptation include self-service telephone dialing (as described above), gasoline purchases, ATM machines, and the like. On the other hand, if products and services continue to increase in complexity and consumers increasingly demand customization, then automated and self-service delivery models are unlikely to be effective. Under these circumstances, the business case for mass customization and high involvement strategies may be more viable. In sum, our research on call center performance models must address these issues, incorporating an understanding of marketing, consumer behavior, technology, and operations management into our models of human resources and industrial relations. 


\section{References}

Appelbaum, E., Bailey, T., Berg, P., \& Kalleberg, A.L. (2000). Mamufacturing Advantage, Ithaca: Cornell University Press.

Barney, J. (1995). 'Looking inside for competitive advantage.' Academy of Management Executive, 9:4, 49-61.

Batt, R. (2000). 'Strategic segmentation and frontline services: Matching customers, employees, and human resource systems.' International Journal of Human Resource Management, 11:3, $540-61$.

Batt, R. (1999). 'Work organization, technology, and performance in customer service and sales.' Industrial and Labor Relations Review, 52:4, 539-564.

Batt, R. (2002). 'Managing customer services: Human resource practices, quit rates, and sales growth.' Academy of Management Journal, 45:3.

Becker, B. \& Gerhart, B. (1996). 'Special research forum: Human resource management and organisational performance.' Academy of Management Journal, 39, 779-801.

Brown, J.S., \&, Duguid, P. (1991). 'Organizational learning and communities-of-practice: Toward a unified view of working, learning, and innovation.' Organization Science, 2:1, 40-57.

Campion, M.A., Medsker, G.J., \& Higgs, C.A. (1993). 'Relations between work group characteristics and effectiveness: Implications for designing effective work groups.' Personnel Psychology, 46, 823-850.

Campion, M.A., Papper, E.M., and Medsker, G.J. (1996). 'Relations between work team characteristics and effectiveness: A replication and extension.' Personnel Psychology, 49:2, 429459

Cannon-Bowers, J.A., Salas, E., \& Converse, S.A. (1993). 'Shared mental models in expert decision making teams' in Current Issues in Individual and Group Decision Making. N.J. Castellan Jr. (ed), Hillsdale: Lawrence Erlbaum Associates.

Cappelli, Peter and David Neumark, 2001. "Do "High-Performance" Work Practices Improve Establishment-Level Outcomes?" Industrial and Labor Relations Review 54(4): 737-75.

Carayon, P. (1993). 'Effect of electronic performance monitoring on job design and worker stress: Review of the literature and conceptual model.' Human Factors, 35, 385-95.

Chase, R.B. (1978). 'Where Does the Customer Fit in a Service Operation?' Harvard Business Review, 56:6, 137-142. 
Cohen, S., \& Ledford, G. (1994). 'The effectiveness of self-managing teams: A quasiexperiment.' Human Relations, 47:1, 13-43.

Cohen, S.G., Ledford, G.E., \& Spreitzer, G. (1996). 'A predictive model of self-managing work team effectiveness.' Human Relations, 49, 643-676.

Cohen, S.G., \& Bailey, D. (1997). 'What makes teams work: group effectiveness research from the shop floor to the executive suite.' Journal of Management, 23, 239-290.

Cotton, J. L. (1993). Employee Involvement: Methods for Improving Performance and Work Attitudes. Newbury Park: Sage Publications.

Datamonitor. (1998). Call centers in Europe 1996-2001: Vertical market opportunities, London: Datamonitor.

Datamonitor. (1999). Opportunities in US and Canadian call center markets, NY: Datamonitor.

Deery, S., Iverson, R., \& Walsh, J. (1999). 'Work relationships in telephone call centers: Understanding emotional exhaustion and employee withdrawal.'

Gladstein, D.L. (1984). 'Groups in context: A model of task group effectiveness.' Administrative Science Quarterly, 29, 499-517.

Godard, J. (2001). 'High performance and the transformation of work? The implications of alternative work practices for the experience and outcomes of work.' Industrial \& Labor Relations Review, 54:4, 776-805.

Gutek, B. (1995). The Dynamics of Service : Reflections on the Changing Nature of Customer/Provider Interactions, San Francisco: Jossey-Bass.

Hackman, R.J., \& Oldham, G.R. (1980). Work Redesign, Reading: Addison-Wesley Publishing Company.

Heskett, J., Sasser, W.E., Jr., \& Schlesinger, L. (1997). The Service Profit Chain: How Leading Companies Link Profit and Growth to Loyalty, Satisfaction, and Value, New York: Free Press.

Hinsz, V R., Tindale, S. \& Vollrath, D. (1997). 'The emerging conceptualization of groups as information processors.' Psychological Bulletin, 121:1, 43-64.

Holman, D. (2001). 'Employee Stress in Call Centres.' Call Centres and Beyond: the Human Resource Management Implications, Kings College, London, November $6^{\text {th. }}$

Holman, D., Chissick, C., \& Totterdell, P. (2002, in press). 'The effects of performance monitoring on emotional labour and well-being in call centers.' Motivation and Emotion. 
Houseman, S. (2001). 'Why employers use flexible staffing arrangements: Evidence from an establishment survey.' Industrial and Labor Relations Review, 55:1, 149-70.

Hutchinson, S., Purcell, J., \& Kinnie, N. (2000). 'Evolving high commitment management and the experience of the RAC call center.' Human Resource Management Journal, 10:1, 63-78.

Ichniowski, C., Kochan, T., Levine, D., Olson, C., \& Strauss, G. (1996). 'What works at work: Overview and assessment.' Industrial Relations, 35:3, 299-334.

Johnson, J. (1996). 'Linking employee perceptions of service climate to customer satisfaction.' Personnel Psychology, 49, 833-851.

Kaplan, R., \& Norton, D. (1996). The Balanced Scorecard: Translating Strategy into Action, Boston: Harvard Business School Press.

Klimoski, R., \& Mohammed, S. (1994). 'Team mental model: Construct or metaphor?' Journal of Management, 20, 403-437.

Kohl, G. (1993). 'Information technology and labor: A case study of telephone operators.' Workplace Topics, 3:1, 101-111.

Lawler, E. E. III. (1986). High-involvement Management: Participative Strategies for Improving Organizational Performance, San Francisco: Jossey-Bass.

Leidner, R. (1993). Fast Food, Fast Talk: Service Work and the Routinization of Everyday Life, Berkeley: University of California Press.

Levitt, T. (1972). 'Production line approach to services.' Harvard Business Review. 50:5, 41-50.

Liang, D.W., Moreland, R., \& Argote, L. (1995). 'Group versus individual training and group perfromance: the mediating factor of transactive memory.' Personality and Social Psychology Bulletin, 21, 384-393.

Locke, E., \& Schweiger, D.M. (1979). 'Participation in decision-making: One more look.' Research in Organizational Behavior, 1, 265-339.

Loveman, G. W. (1998). 'Employee satisfaction, customer loyalty, and financial performance: An empirical examination of the service profit chain in retail banking.' Journal of Service Research, 1:1, 18-31.

MacDuffie, J. P. (1995). 'Human resource bundles and manufacturing performance: Organizational logic and flexible production systems in the world auto industry.' Industrial and Labor Relations Review, 48, 197-221.

Mathieu, J.E., Heffner, T.S., Goodwin, G.F., Salas, E., \& Cannon-Bowers, J.A. (2000). 'The influence of shared mental models on team processes and performance.' Journal of Applied 
Psychology, 85, 273-283.

Moynihan, L., \& Batt, R. (2001). 'Knowledge sharing and performance of teams in call centers.'

Orr, J. (1996). Talking About Machines: An Ethnography of a Modern Job, Ithaca: Cornell University ILR Press.

Pearce, J.A. \& Ravlin, E.C. (1987). 'The design and activation of self-regulating work groups.' Human Relations, 40, 751-782.

Pine, B.J. (1993). Mass Customization, Cambridge: Harvard Business School Press.

Purdue University. (1999). 'Call Center Benchmarking Report.'

Ramsay, H., Scholarios, D., \& Harley, B. 2000. 'Employees and high-performance work systems: Testing inside the black box.' British Journal of Industrial Relations, 38:4, 501-531.

Ryan, A.M., Schmit, M., \& Johnson, R. (1996). 'Attitudes and effectiveness: Examining relations at an organizational level.' Personnel Psychology, 49, 853-81.

Sargent, A, \& Frenkel, S. (2000). 'When do customer contact employees satisfy customers?' Journal of Service Research, 3:1, 18-34.

Schacht, J., (1985). The Making of Telephone Unionism 1920-1947, New Jersey: Rutgers University Press.

Schlesinger, L., \& Zornitsky, J. (1991). 'Job satisfaction, service capability, and customer satisfaction: An examination of linkages and management implications.' Human Resources Planning, 14:2, 141-149.

Schmit, M., \& Allscheid, S. (1995). 'Employee attitudes and customer satisfaction: Making theoretical and empirical connections.' Personnel Psychology, 48, 527-47.

Schneider, B., \& Bowen, D.E. (1985). 'Employee and customer perceptions of service in banks: Replication and extension.' Journal of Applied Psychology, 70, 423-433.

Schneider, B., Wheeler, J., \& Cox, J. (1992). 'A passion for service: Using content analysis to explicate service climate themes.' Journal of Applied Psychology, 77, 705-716.

Schneider, B., White, S., \& Paul, M. (1998). 'Linking service climate and customer perceptions of service quality: Test of a causal model.' Journal of Applied Psychology, 83:2, 150-63.

Singh, J. (2000). 'Performance, productivity, and quality of frontline employees in service organizations.' Journal of Marketing, 64:April, 15-34. 
Singh, J., Goolsby, J., \& Rhoads, G. (1994). 'Behavioral and psychological consequences of boundary spanning: Burnout for customer service representatives.' Journal of Marketing Research, 31:November, 558-69.

Singh, J., Berbeke, W., \& Rhoads, G. (1996). 'Do organizational practices matter in role stress processes? A study of direct and moderating effects for marketing-oriented boundary spanners.' Journal of Marketing, 60:July, 69-86.

Stasser, G. (1992). 'Information salience and the discovery of hidden profiles by decisionmaking groups: A "thought experiment." Organizational Behavior and Human Decision Processes, 52, 156-181.

Stasser, G., \& Titus, W. (1985). 'Pooling of unshared information in group decision making: Biased information sampling during discussion.' Journal of Personality and Social Psychology, 48, 1467-1478.

Sutton, R. I., \& Rafaeli, A. (1988). 'Untangling the relationship between displayed emotions and organizational sales: The case of convenience stores.' Academy of Management Journal, 31:3, 461-487.

Taylor, P., \& Bain, P. (2001). 'Trade unions, workers' rights, and the frontier of control in UK call centers.' Economic and Industrial Democracy, 22, 39-66.

Tornow, W.W., \& Wiley, J.W. (1991). 'Service quality and management practices: A look at employee attitudes, customer satisfaction, and bottom-line consequences.' Human Resource Planning, 14:3, 105-115.

Ulrich, D., Halbrook, R., Meder, D., Stuchlik, M. \& Thorpe, S. (1991). 'Employee and customer attachment: Synergies for competitive advantage.' Human Resources Planning, 14:3, 89-103.

Wegner, D.M. (1987). 'Transactive memory: A contemporary analysis of the group mind' in Theories of group behavior. B. Mullen \& G.R. Goethals (eds), New York: Springer-Verlag.

Wood, S. (1999). 'Human Resource Management and Performance.' International Journal of Management Reviews, 1:4, 367-413.

Wiley, J.W. (1991). 'Customer satisfaction: A supportive work environment and its financial costs.' Human Resources Planning, 14:3, 117-127.

Wright, P., Dyer, L., Boudreau, J., and Milkovich, G., eds. 1999. Research in Personnel and Human Resource Management: Strategic HRM in the $2 I^{\text {st }}$ Century. Supplement 4. Greenwich, CT: JAI Press.

Yammarino, F.J., \& Dubinsky, A.J. (1990). 'Salesperson performance and managerially controllable factors: An investigation of individual and work group effects.' Journal of Management, 16, 87-106. 
Table 1: Mean Characteristics of Call Centers by Customer Segment and HR Practices

Operators Residential Small business Large business

High involvement index score (0-100)

Lower* Higher** Lower Higher Lower Higher

Outcomes

Annual quit rate

$\%$ change in sales

Average call handling time

Average customers/employee/day

27.53

32.66

$53.12 \quad 36.51$

$58.49 \quad 48.76$

72.29

20.31

20.98

$$
9.20
$$

10.80

16.05

36.78

16.36

12.45

18.66

$0.52 \quad 5.47$

6.43

25.79

58.18

34.76

11.79

$460 \quad 127$

9.59

10.55

39.76

$72-4.88$

39

19

42

Specific Management Practices

Skill requirements of jobs

Years of education

Weeks to become proficient

Days of on-going training/year

Technology use

\# software programs typically used

$\%$ of day electronically monitored

Work design

$\%$ of workforce in problem-solving teams

$\%$ of workforce in self-directed teams

$\begin{array}{rrrrrrr}12.21 & 12.52 & 13.52 & 13.07 & 14.51 & 14.39 & 15.91 \\ 11.15 & 13.71 & 20.32 & 12.33 & 32.34 & 19.57 & 35.18 \\ 0.67 & 1.41 & 2.67 & 1.39 & 2.43 & 2.15 & 2.52 \\ & & & & & & \\ 1.13 & 3.06 & 4.22 & 3.09 & 4.87 & 4.97 & 8.17 \\ 75.00 & 59.64 & 38.63 & 44.19 & 23.50 & 35.32 & 7.66 \\ & & & & & & \\ 48.87 & 27.96 & 61.61 & 36.20 & 60.98 & 45.72 & 68.86 \\ 6.67 & 2.16 & 28.43 & 5.28 & 19.13 & 13.79 & 38.43 \\ & & & & & & \\ 79.66 & 80.02 & 91.81 & 81.15 & 95.43 & 91.77 & 99.06 \\ & & & & & & \\ 16,353 & 20,440 & 25,291 & 22,908 & 23,400 & 26,988 & 48,069 \\ 19,061 & 24,372 & 33,465 & 27,953 & 44,429 & 48,375 & 76,258 \\ 11.67 & 10.61 & 16.84 & 14.74 & 41.26 & 34.68 & 34.83 \\ & & & & & & \\ 0.33 & 0.22 & 0.22 & 0.13 & 0.12 & 0.06 & 0.03 \\ 15.29 & 23.50 & 31.57 & 32.60 & 48.44 & 52.00 & 56.26 \\ 15 & 52 & 54 & 45 & 41 & 32 & 35\end{array}$

HR Incentives, Rewards

Employment Security

$\%$ workforce permanent and fulltime

Compensation

Annual base pay of median worker

Annual total pay of median worker

$\%$ of pay that is variable

Organizational Characteristics

$\%$ of establishments that are union

$\%$ workforce that is male

15

52

$54 \quad 45 \quad 41 \quad 32$

$* *$ Lower refers to centers scoring less than the mean of the high involvement index for the customer segment
$*$ Higher refers to centers scoring more than the mean of the high involvement index for the customer segment 
Table 2

Bi-variate Correlations of Management Practices, Knowledge-sharing, and Performance

\begin{tabular}{|l|c|c|}
\hline Dimensions of Work System & Knowledge & Usage \\
\hline Knowledge-sharing & & \\
\hline Knowledge of others expertise & 1.00 & \\
\hline Usage of others expertise & $.56^{* *}$ & 1.00 \\
\hline $\begin{array}{l}\text { Technology Use and Skill } \\
\text { Requirements }\end{array}$ & & \\
\hline Number of software programs & $.20^{*}$ & .10 \\
\hline Number of program updates & & $.22^{* *}$ \\
\hline Work Design & $.52^{* *}$ & $.30^{* *}$ \\
\hline Task interdependence & $.33^{* *}$ & $.27^{* *}$ \\
\hline Resource interdependence & $.33^{* *}$ & $.27^{* *}$ \\
\hline Task variety & & $.22^{*}$ \\
\hline Supportive HR Practices & $-.16^{*}$ & -.02 \\
\hline Shared goals and outcomes & $.32^{* *}$ & $.42^{* *}$ \\
\hline Shared training & & -.12 \\
\hline Group recognition & -.12 & .16 \\
\hline Worker Actions and Performance & $.23^{*}$ & $-.29^{* *}$ \\
\hline Call handling time & $-.48^{* *}$ & $.36^{* *}$ \\
\hline Objective call quality audit & $.36^{* *}$ & $.59^{* *}$ \\
\hline Perceived process loss & $.34^{* *}$ & $.20^{*}$ \\
\hline Perceived peer learning & & \\
\hline Innovation and problem-solving & & \\
\hline Self-reported job satisfaction & & \\
\hline
\end{tabular}

* Statistical relationship significant at p. $<.05 ; * *$ p. $<.01$. 